\title{
How the Law Learns in the Digital Society
}

\author{
Christoph B. Graber ${ }^{1}$ \\ University of Zurich, Switzerland
}

\begin{abstract}
Recent court decisions have revealed how the law is frequently under pressure to adjust to novel digital technologies. As legal practice is blind to the factual particularities of the relationship between law and technology, the courts' efforts to re-stabilize normative expectations of Internet users, in the face of sociotechnical changes caused by computer networks, lack an adequate theoretical classification. Science and technology studies (STS) provide refined knowledge on the interaction between technology and society. Yet, the law and normative structures have remained a stepchild of that branch of interdisciplinary theorizing within the social sciences. Within the legal discipline, media-based theories about the law in the digital environment have conceived computer networks as hybrid sociotechnical constructs. This approach aptly shows how digital media have changed the way individuals experience the world and interact with one another and how the capacity to adjust cognitive behavioral expectations to new developments has become crucial. While the learning of individuals takes center stage, this perspective belittles the relevance of normative expectations and overlooks the law's learning. How is the law capable of learning under conditions of computer networks and responding to the sociopolitical changes caused by the new technologies? This paper's aim is to propose a perspective on the law in the digital society that combines STS with legal sociology. An approach based on technical affordances explains how normative behavioral expectations can adjust to changes in the networked environment and how the law learns in the digital society.
\end{abstract}

Keywords: Legal Sociology; Affordance Theory; STS; Media Theory; Law and Technological Change.

\section{Introduction}

"Right to be Forgotten," "Google thumbnails," "Net neutrality," and "Facebook Like button" are shorthand formulas associated with spectacular judgments recently passed by major courts in the European Union and the United States. A shared characteristic of these cases is the deciding court's endeavor to adjust the law to new operating conditions caused by changes in the digital network. As this is not a court's primary task, the verdicts do not provide a thorough analysis of the peculiar intermingling of the social and the technological, which is common to them all.

Germany's Bundesgerichtshof (BGH, Federal Court of Justice), for example, was recently impelled to adapt copyright law to the technical functioning of Internet search engines. The BGH concluded that visual artists or photographers, having authorized third parties to make reproductions of their works available on the Internet, cannot crackdown on Google when it displays thumbnails of these images in response to a respective search query. Thus, the court established a novel privilege for Internet search engines consisting of the presumption that right holders who have not taken any specific technical measures preventing search engines from indexing images have implicitly consented to that. ${ }^{2}$ For revocation of the right holder's informal consent, verbal communication would not be enough; to be legally effective, the right holder would need to take technical safeguards hindering the search engine from finding the uploaded works at all. ${ }^{3}$ Tacitly, the BGH's ruling contains a double realization. First, normative behavioral expectations can change and adapt to novel technologies in the digital networked environment, and second, the functional particularities of search engine technology may require copyright law to strike a new balance between the normative expectations of right holders and those of users.

\footnotetext{
${ }^{1}$ Professor of Law, PhD, Chair for Legal Sociology and Media Law at the University of Zurich. For helpful comments, I would like to thank Jessica Lai and Thomas Vesting. Special thanks go to the anonymous reviewers and the editorial team of Law, Technology and Humans.

2 “Thumbnails II," Bundesgerichtshof, I ZR 140/10, October 19, 2011, para 49.

3 “Thumbnails I," Bundesgerichtshof, I ZR 69/08, April 29, 2010, para 37.
}

Except where otherwise noted, content in this journal is licensed under a Creative Commons Attribution 4.0 International Licence. As an open access journal, articles are free to use with proper attribution. ISSN: 2652-4074 (Online) 
The judgments of the Court of Justice of the European Union (CJEU) regarding the "Right to be Forgotten" 4 and the "Facebook Like button," and the decision of the Court of Appeals for the District of Columbia Circuit on "Net neutrality" are further examples where the judiciary was forced to re-stabilize normative expectations under conditions of digital networks. What is it about such novel phenomena of techno-social normativity?

I do not agree with Karavas, who speaks in this context of an "amalgamation of normative and digital expectations inside the digital medium." There is no such thing as "digital expectations." The expecting actor is necessarily an epistemic subject, that is, a human being or social system ${ }^{8}$ capable of generating intentions that guide their actions. According to Searle, machines are not capable of developing intentions. ${ }^{9}$ Even if we understand machines as actors to which intentions can be ascribed, this involves - in the sense of Searle's distinction-derivative rather than original intentionality. ${ }^{10}$ Searle argues that computers do not have original intentionality as this term refers to mental states. We can only speak of derivative intentionality in the sense that we are able to interpret a computer's operations. ${ }^{11}$

Enthusiasts of artificial intelligence (AI) may argue that self-learning machines will sooner or later gain a degree of relative autonomy and then possess something like consciousness. ${ }^{12}$ Leaving aside the merely speculative nature of such prognostics, the distinction between consciousness and self-consciousness needs to be emphasized. Consciousness is something that some animals also possess. Dogs, for example, can behave in ways that cause their owners to play with them, feed them or caress them. Although a dog may possess consciousness, self-consciousness will be missing. ${ }^{13}$ Self-consciousness describes the capability of reflection. It refers to the capacity to observe oneself from a second-order perspective and reconsider one's own behavior from a different (e.g., moral) point of view. Dogs do not possess reflective competence; they are unable to recognize their mirror image, for example. The same holds true for machines; the ability to observe their own operations from a secondorder perspective is missing. Only humans (and social systems) are epistemic subjects. They alone can form a mental image of what they are, want to be, or should be, and accordingly plan or adapt their behavior.

Rather than "digital expectations," normative expectations about the behavior of technologies should be our focus. In what follows, the paper argues that normative expectations about the behavior of digital technologies emerge from society andunder certain conditions - may become institutionalized as law. The point is that normative behavioral expectations can adapt to changing conditions of the digital networked environment, thus, paving the way for the law's learning. But how should we understand the law's learning in the digital society? What is the theoretical perspective allowing the conceptualization of such processes of norm generation, stabilization, and generalization in the sociotechnical realm?

While legal doctrine and the reasoning of courts are mostly blind to the relationship between law and technology in the digital society, ${ }^{14}$ STS has been producing sophisticated knowledge about the interaction between technologies and society since the 1970s. However, the law and normative structures have remained a stepchild of that branch of social theorizing. Within the legal discipline, Vesting and Ladeur have developed a media theory perspective on the law in the age of computer networks. For Vesting, media are conditions of possibility for the law. Reconstructing the historical development of society in Western Europe since ancient times, he argues that the form and materiality of dissemination media, including the spoken language, writing, printing, and computer networks, have always been a means of pre-structuring and co-shaping the development of law. ${ }^{15}$ The computer network, the dominant dissemination medium of the twenty-first century, is perceived by Vesting as a hybrid construct intermingling the material and the social. Endorsing a media theory perspective such as Vesting's, Ladeur claims that learning has become crucial in the twenty-first century's "society of networks." 16 As the society of networks has

\footnotetext{
4 "Right to be Forgotten," CJEU, C-131/12, May 13, 2014.

${ }^{5}$ Fashion ID v Verbraucherzentrale NRW, CJEU, C-40/17, July 29, 2019.

${ }^{6}$ United States Telecom Association v FCC, USCA 15-1063 (DC Circuit), June 14, 2016.

${ }^{7}$ Karavas, "Force of Code," 478.

${ }^{8}$ For an account of the legal system as an epistemic subject see Teubner, "How the Law Thinks," 727-757.

${ }^{9}$ Searle defines "intentionality" as "the capacity of the mind to represent objects and states of affairs in the world other than itself." Searle, Construction of Social Reality, 6-7.

${ }^{10}$ Searle presented this argument for the first time in his 1980 article "The Chinese Room Argument" and has since revised it several times. See Cole, "Chinese Room Argument," para 5.2.

${ }^{11}$ Searle's assumptions about the physical state of machines are consistent with his thesis that "external realism" is the precondition for

"conceptual relativism." For Searle's combination of external realism with conceptual relativism see n.107, and surrounding text.

${ }^{12}$ See Cole, "Chinese Room Argument."

${ }^{13}$ For a similar view, see Korsgaard, Fellow Creatures, 23-51.

${ }^{14}$ Cockfield and Pridmore explain this by the dominance of an "instrumental theory" of technology in legal practice. Cockfield, "Synthetic Theory," 497. According to the authors, an instrumental theory perceives "technology as a neutral tool without examining its broader social, cultural, and political impacts." (476).

${ }^{15}$ Vesting, Legal Theory and Media of Law.

${ }^{16}$ Ladeur, "Die Netzwerke des Rechts," 143-171.
} 
radically changed the way individuals experience the world and interact with one another, the capacity to adjust behavioral expectations to new developments has become paramount.

The approach of Vesting and Ladeur will be discussed below as a promising way toward an integration of technological materiality into a theory of law in the twenty-first century. However, the paper will question their understanding of the computer network as a sociotechnical hybrid as well as the primacy of cognitive mechanisms of adaption compared with normative patterns of orientation. Departing from these theories, the paper will propose an alternative perspective on normative expectations and the law in the digital society that combines STS with legal sociology. The connection between STS and legal sociology is the concept of technical affordances, which are opportunities or constraints of a technology that are co-shaped within the processes of material design and social interpretation. An affordance-based approach to law and society shows how normative behavioral expectations can adjust to changes in the networked environment and how the law learns in the digital society.

\section{Law in the Digital Society}

\subsection{The Perspective of Science and Technology Studies}

STS refers to a field of interdisciplinary research that took shape in the 1970s, mostly in Europe and Northern America. ${ }^{17}$ The field continues to thrive today and has successfully institutionalized itself with specialized chairs at prestigious universities. As an acronym, STS stands for science and technology studies but has sometimes also been used as a collective term for the entire field of science, technology, and society. Dissociating from classic positions and positivistic premises in the theory and sociology of science, ${ }^{18}$ STS has broadly opted for a social constructivist research method. ${ }^{19}$

Scientific positivists were convinced that "collecting accurate data, generating logical generalizations which [sic] explain that data, and testing those data" 20 was characteristic of the scientific method. STS scholars, in contrast, are more interested in studying "how science (and technology) work in practice." ${ }^{21}$ The focus on practice is shared by the most important dynamics within the broader STS framework, including SSK (the sociology of scientific knowledge), SCOT (the social construction of technology), ANT (actor-network theory), and many feminist technoscience studies. ${ }^{22}$ Rather than following positivism, STS argues that "technoscience practices are methods that shape and reproduce the social world." 23 Scientific truth and technical artifacts are viewed as social practices in specific contexts; social constructivism is a general feature of STS. ${ }^{24}$

In addition to antipositivism, antideterminism is a characteristic of social constructivism and STS. According to a determinist view, "the development of technology proceeds in an autonomous manner, determined by an internal logic independent of social influence." ${ }^{25}$ This position has been widely criticized in the literature, ${ }^{26}$ and it is difficult to find authors who would explicitly support it. ${ }^{27}$ Rejecting technological determinism, social constructivist versions of STS claim that society can influence or shape technology, objecting to the view that a designer who creates an artifact determines the range of the object's potential uses. Hence, social constructivism insists on the possibility of flexibility in the user response to the original design. Technologies are perceived to be underdetermined ${ }^{28}$ or "multistable" to use Ihde's term. ${ }^{29}$ Underdetermination of an artifact leaves room for its interpretation. ${ }^{30}$ There is interpretive flexibility not only when the artifact is designed but also in its subsequent uptake. ${ }^{31}$

\footnotetext{
${ }^{17}$ For an overview see Sismondo, Science and Technology Studies, 10.

${ }^{18}$ Zammito, Derangement of Epistemes; see Giere, "What Everyone Should Know," 489-493.

${ }^{19}$ Feenberg, Technosystem, 38-40, considers social constructivism and actor-network theory (ANT) two main currents of STS.

${ }^{20}$ Law, "STS as Method," 32.

${ }^{21}$ Law, "STS as Method," 31.

${ }^{22}$ Law, "Performing Technology's Stories," 766.

${ }^{23}$ Law, "STS as Method," 31.

${ }^{24}$ Bijker, "Technology," 135.

${ }^{25}$ Kline, "Technological Determinism," 109.

${ }^{26}$ See, for example, Cockfield, "Synthetic Theory," 489-494.

${ }^{27}$ Grint, Machine at Work, 7.

${ }^{28}$ Feenberg, Technosystem, 115.

${ }^{29}$ Ihde, Technology and Lifeworld, 144.

${ }^{30}$ Feenberg, Technosystem, 46; Sismondo, Science and Technology Studies, 6; see also Woolgar, "Do Artefacts Have Ambivalence?" 443444. For an account of underdetermination of information technology see Doherty, "A Re-conceptualization," 569-582.

${ }^{31}$ Pinch, "Facts and Artifacts," 40; Feenberg, Technosystem, 154-157.
} 
Some STS scholars have defended a radical constructivist perspective on technology. ${ }^{32}$ In its most extreme form, social constructivism has claimed that "technology does not have any influence which [sic] can be gauged independently of human interpretation." 33 According to that thesis, technology is essentially social, ${ }^{34}$ "it is a construction rather than a reflection of the machine's capabilities." 35 Other approaches to STS have objected to such absolutization of society. Criticizing radical constructivism's overemphasis on human intention, Latour's version of ANT argues for a symmetry of human and non-human actors, or "actants," linked together in hybrid networks. ${ }^{36}$ His book We Have Never Been Modern postulates "symmetry between the two branches of government, that of things — called science and technology — and that of human beings." 37 In Politics of Nature, Latour attributes agency to new types of "actants" that are not human actors. ${ }^{38}$ Latour uses the adjective "hybrid" to refer to the dissolution of the distinction between things and humans or nature and society. ${ }^{39}$ For Latour, nature and humans are inextricably intertwined in hybrid "socio-technological networks." 40 Thus, he argues for an "essential connection between technology and society," which is articulated in a process of co-production. ${ }^{41}$ Co-production is a convincing concept for understanding the relationship between society and technology ${ }^{42}$ and will, thus, be informing arguments that are further developed below.

What does STS say about the law? A few STS scholars, most prominently Jasanoff and Lynch, have contributed important work analyzing the interrelationship between science, technology, and law. These writings have primarily engaged in microsociological studies ${ }^{43}$ on select questions of law, science, and technology, including the use of science and technology in courtrooms ${ }^{44}$ or law and technology relationships in intellectual property ${ }^{45}$ and environmental regulation. ${ }^{46}$ STS scholars writing about law-related issues are the exception rather than the rule. For example, of Lynch's encyclopedic compilation of the 70 seminal conceptual articles in the history of STS, only one is directly related to the law. ${ }^{47}$ STS has been reproached for lacking an element of social critique. ${ }^{48}$ As STS has mostly focused on case studies, ${ }^{49}$ it has not developed a more generalized theory about the law in relation to science and technology. What is more, social scientists working in STS are unable to understand the law's normativity, ${ }^{50}$ which, as will be argued below with reference to Weber and Hart, requires an internal perspective on the law.

Of course, insider and outsider perspectives have been distinguished in the etic-emic debates in anthropology since the 1960s. "Etic" describes a standpoint in anthropological research that observes cultural contexts from outside, ${ }^{52}$ allowing an STS scholar to notice regularities between specific technologies and the practice of law-creating and law-applying agencies. ${ }^{53}$ "Emic" refers to a perspective gained through the researcher's immersion into a culture or group. ${ }^{54}$ Such studies go beyond mere data-gathering and often provide more detailed and culturally rich information and a deeper understanding of a group's interactions. However, as STS scholars are generally not trained as jurists, they lack the technical and doctrinal expertise necessary to understand legal proceedings and normative structures. An example is Latour, whose work has been influential in STS scholarship. In his book The Making of Law, he attempts to define the law on the basis of an ethnography of the French Conseil d'Etat, a court-like institution. ${ }^{55}$ For Latour, law is defined as "strategically positioned networks" which "connect and

\footnotetext{
${ }^{32}$ See Bijker, "Technology," 135.

${ }^{33}$ Grint, Machine at Work, 10.

${ }^{34}$ Pinch, "Facts and Artifacts."

${ }^{35}$ Grint, Machine at Work, 10.

${ }^{36}$ Feenberg, "Critical Theory," 640; see also Sayes, “Actor-Network Theory," 134-149; Verbeek, "Artifacts and Attachment," 125.

${ }^{37}$ Latour, Never Been Modern, 138.

${ }^{38}$ Latour, Politics of Nature, 62-70; see also Latour, Science in Action, 84.

${ }^{39}$ Latour, Never Been Modern, 10-11.

${ }^{40}$ Latour, Never Been Modern, 91.

${ }^{41}$ Feenberg, Technosystem, 75.

${ }^{42}$ Jasanoff, "Idiom of Co-Production," 1-12.

${ }^{43}$ For Zammito, Derangement of Epistemes, 151-182, the turn to microsociological studies is a distinctive feature of STS constructivism.

${ }^{44}$ See, for example, Jasanoff, Science at the Bar; Jasanoff, "Law's Knowledge," S49-S58; Jasanoff, "Just Evidence," 328-341; Jasanoff,

"Making Order," 761-786; Lynch, "Studies on Trial," 269-311; Lynch, Truth Machine.

${ }^{45}$ For example, Biagioli, "Technologies of the Law," 3-17.

${ }^{46}$ For example, Pottage, "Biotechnology," 105-125; Jasanoff, "Risk and Precaution," 277-282; Jasanoff, "Science and Judgment," $107-120$.

${ }^{47}$ Lynch (ed.), Science and Technology Studies; the respective article is: Smith, "Unquiet Judge."

${ }^{48}$ See, for example, Feenberg, Technosystem; Couldry, "Recovering Critique," 1135-1151.

${ }^{49}$ Law, "STS as Method," 32.

${ }^{50}$ Faulkner, "Material Worlds," 1-19; Cole, "Science, Technology, Society, Law," 351-371.

${ }^{51}$ Headland, Emics and Etics.

52 Mostowlansky, "Emic and Etic," 1-16.

${ }^{53}$ For an overview see Cole, "Science, Technology, Society, Law," 361.

${ }^{54}$ Mostowlansky, "Emic and Etic."

${ }^{55}$ Latour, Making of Law; for a discussion see Pottage, "Materiality of What?" 167-183.
} 
bind disparate and seemingly unrelated things, documents, and people." 56 This definition falls short of understanding legal normativity and grasping the distinguishing feature of norms that are voluntarily accepted by their addressees. ${ }^{57}$ STS is, thus, unable to adopt the lawyer's habitual perspective and ask the questions about normativity that Weber associated with the law's internal point of view: "What is intrinsically valid as law? That is to say: What significance or, in other words, what normative meaning ought to be attributed in correct logic to a verbal pattern having the form of a legal proposition[sic]" 58

The distinction between external and internal perspectives on the law is crucial as, according to Hart, an "external" observer is unable to understand what "constitutes the normative structure of society." 59 Following Hart's concept of law, a distinction must be made between "being obliged" and "being under an obligation" to do something. ${ }^{60}$ This argument is also relevant in the digital environment. The point is that coercive effects of technology need to be distinguished from normative structures and law. For example, a user of an e-book, which is protected by a digital rights management system (DRM), is right to say that she is obliged by the technology if the DRM factually restrains her use of the book. This would be the case if the DRM prevents her by technical means from saving a copy of the e-book on her computer, notwithstanding the copyright statute's permission to make a private copy. However, the user would be wrong to state that she is under an obligation to follow the DRM rule because of the DRM's lack of legal legitimacy. For Hart, the question of whether someone is under an obligation refers to the "internal aspect of rules," ${ }^{61}$ that is, how legal subjects themselves observe the rules, whether they accept the rules, and whether they consider the rules legitimate. The internal aspect is a prerequisite of primary rules of obligation, which, in union with secondary rules, are the defining features of law. ${ }^{62}$

\subsection{A Media Theory of the Law}

The discussion of STS research and its relationship with the law has revealed the strengths and limitations of the debate. The strengths are in its capability to conceive the relationship between society and technology as one of co-production. However, as the framing of internal aspects of the law is not its point, STS is unable to grasp the essence of legal normativity. Insisting on the difference between a social scientist's and a jurist's perspective, I would like to introduce Vesting's and Ladeur's theorizing on law and technology. As a legal perspective, it is markedly different from the STS viewpoint.

Vesting and Ladeur are both German jurists and legal theorists. Over the last decade, they have contributed to the development of a media theory of the law that reconstructs the relationship between materiality and law from a media theory perspective. Because most of their publications are in German, their work has gained little attention outside the German language area, although it has strongly influenced the legal debate in Germany. This section provides a critical introduction to their most recent writings about the law in the age of computer networks and advances the paper's argument about the law's learning.

Vesting reverses usual media law approaches as he does not view the media of "language and speech," "writing," "printing," and "computer networks" as mere objects of legal regulation. Neither do these media involve different channels available for the communication of legal knowledge. In his path-breaking work Legal Theory and the Media of Law, ${ }^{63}$ which is the 2018 one-volume English translation of four separate volumes that originally appeared between 2011 and 2015 in German, he conceives media as conditions of possibility of law in specific historical contexts and views their materiality as a means of prestructuring and co-shaping the creation of law. For Vesting, computer networks are the dominant media of the twenty-first century. ${ }^{64}$ His notion of media is informed by McLuhan's theory of media, which — through their materiality-are "extensions of man." ${ }^{65}$ According to Vesting, McLuhan's famous thesis, "the medium is the message," 66 is the key to understanding the concept of media. As the formula has often been misinterpreted, Vesting refers to an interview where McLuhan clarified its meaning as follows: "The medium is hidden, the message is obvious. But the real effect comes from the hidden ground, not from the content, not from the figure." 67 To comprehend the message, one must consider the medium used for its distribution. While the message is manifest, the medium stays invisible. Although it is "hidden ground," the medium is in the foreground of McLuhan's theory. According to Krämer, a media philosopher, "The strategic goal of McLuhan's identification of the medium with the message was to take away the transitory transparency and neutrality of the media and make visible their autonomous

\footnotetext{
56 Cole, "Science, Technology, Society, Law," 361.

57 See Levi, "Studying Law," 805-825.

58 Weber, Economy and Society, 311 (emphasis in the original).

${ }^{59}$ Hart, Concept of Law, 86.

${ }^{60}$ Hart, Concept of Law, 79-86.

${ }^{61}$ Hart, Concept of Law, 86.

${ }^{62}$ Hart, Concept of Law, 89-96.

63 Vesting, Legal Theory and Media of Law.

64 Vesting, Legal Theory and Media of Law, part IV.

65 McLuhan, Understanding Media.

${ }^{66}$ McLuhan, Understanding Media, 7.

${ }^{67}$ McLuhan in an interview as quoted by Vesting, Legal Theory and Media of Law, 442.
} 
opacity and instrumental shaping power." 68 Unlike philosophers who focus on content and its meaning, McLuhan is more interested in the materiality of the medium and the way it shapes content. For McLuhan, the content of any medium "is always another medium. The content of writing is speech, just as the written word is the content of print, and print is the content of the telegraph." ${ }^{69}$ Seconding Krämer, who emphasizes McLuhan's pioneering role in the "medial turn" in cultural studies, ${ }^{70} \mathrm{Vesting}$ observes an "overlapping between media theory and cultural science."71 For Vesting, the medias' materiality must be at the center of media theory, not least because technology supports the communicability of the message. ${ }^{72} \mathrm{He}$ claims that the strict separation of the sphere of meaning from the sphere of the organic or physical components of communication must be abolished. ${ }^{73}$ According to Vesting, there is a dependency of language on the materiality of the medium, which is evident in writing but also applies to other media, including telecommunication, television, and the Internet. ${ }^{74}$

Rather than overemphasizing the effect of technology as a determinant, Vesting's media theory conflates the technical and the social. This becomes most obvious in his conceptualization of the computer network, which appears as a hybrid sociotechnical construct. Quoting the work of Baecker, Castells, Ladeur, and others, Vesting refers to the massive cultural and social effects that the spread of networked computers has caused since the $1960 \mathrm{~s} .{ }^{75}$ According to Vesting, "[t]he crucial change that must be accounted for is the transition from a hierarchical/centralized culture to a heterarchical/acentric one." 76 For Vesting, the idea of the network must not be reduced to a purely technical grid but should rather be conceived as a hybrid construct with multiple intersections between material and social structures in the society of computer networks. ${ }^{77}$ The "material turn" in Vesting's theory affects the relationship between media and the law. According to Vesting, the media-indifferent view of legal communication, which prevails in court practice, should be replaced by an understanding of legal communication that always carries the "trace of the media that it uses." 78 Hence, the mediality of legal communication, ${ }^{79}$ that is, the question of how differences in the medial form change legal communication, takes center stage in Vesting's media theory of law.

Agreeing with Vesting's emphasis on the materiality of media and its effect on the social and legal evolution, ${ }^{80}$ Ladeur has reconstructed the development of society in Western Europe since the end of the nineteenth century. He describes a societal development that is driven by media, leading from the "society of individuals" to the "society of organizations" and finally to the "society of networks." 81 In the society of individuals, the intersubjective coordination (between neighbors) creates a basis of normality and experience upon which normative expectations can build. ${ }^{82}$ In the society of organizations, it is the task of mass media and political parties to mediate between the private-individual and the public-governmental sphere, thus, prestructuring the reproduction of normative expectations. ${ }^{83}$ In the society of networks, a governance model that is defined by new technologies fundamentally alters the conditions of possibility of individual action and autonomy. ${ }^{84}$ A transformation of the individual subject takes place. In the society of networks, the individual must discover experimental thinking and new developments. The creation and renewal of knowledge are linked to a distributed heterarchical network that operates without any central instance mediating the process.

For Ladeur, the theoretical focus must be on the effect that media change has on the relationship between societal actors. Historical media are conceived by Ladeur as specific means that shape communication in society. The computer facilitates the development of new hybrid models to interconnect knowledge and provide access to information. ${ }^{85}$ Like Vesting, Ladeur perceives the computer network as a hybrid sociotechnical construct. ${ }^{86}$ The computer network builds the primary space within which the "relational subjects" of the society of networks constantly configure and reconfigure their mutual relationships. ${ }^{87}$

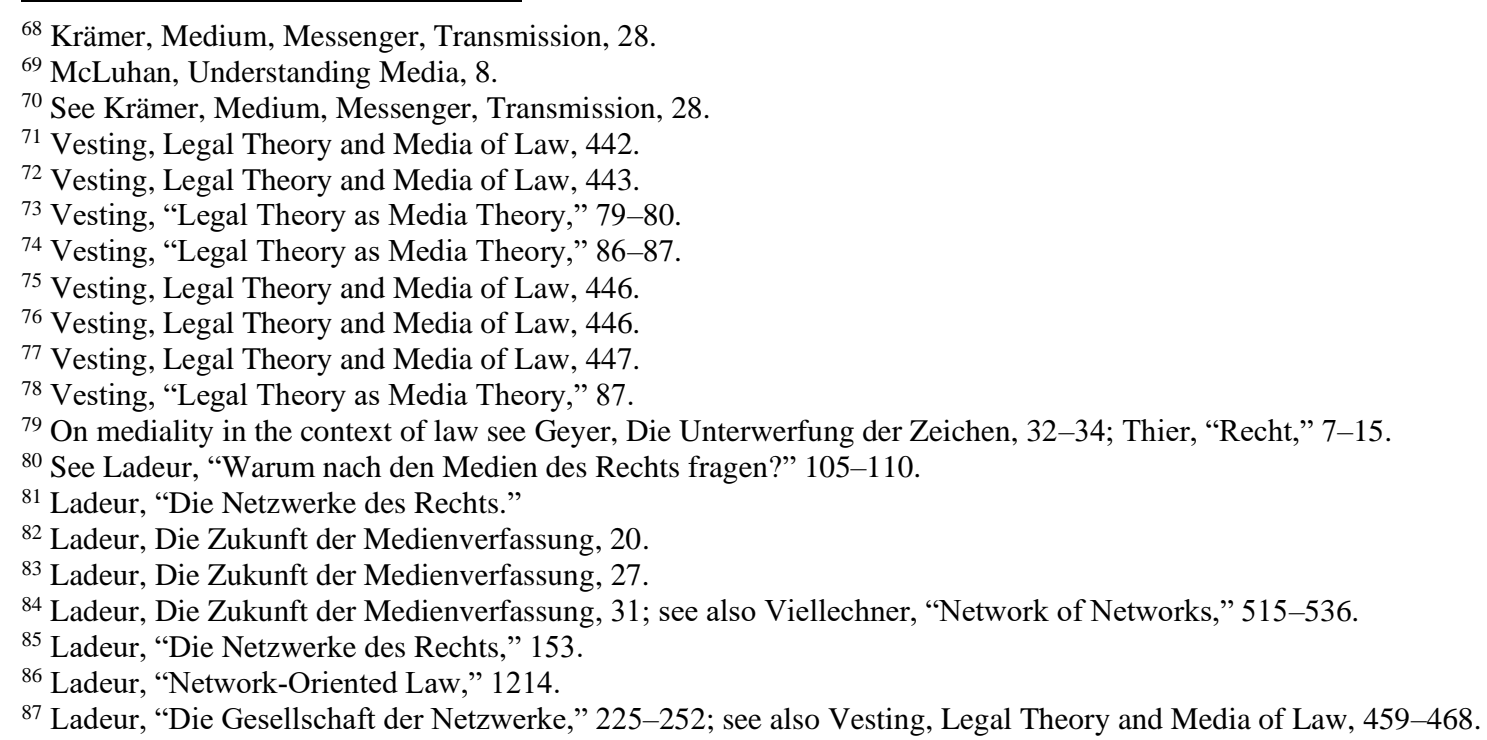


Regarding the law of the society of networks, he states that "the mobilization and hybridization of the relationship between cognitive and normative components of the law can globally be identified as the preeminent feature of the law of the society of networks." ${ }^{88}$ Ladeur claims that cognitive forms of coordination have become more relevant in the formation of behavioral expectations. ${ }^{89}$ Normative behavioral expectations are, thus, upstaged.

In comparison with STS scholarship, Vesting and Ladeur have a sound understanding of legal practice and legal theory. Their media theory perspective on the law allows assessment of the effect of media and materiality on human actors and legal processes. However, a shortcoming of their approach is that perceiving the network as a sociotechnical hybrid removes the distinction between intentional human action and technological causality. Thus, the network's material and social components appear only of secondary importance. Consequently, the possibility of a critique of the technological development and an emancipative reaction to its social costs is lost. Vesting and Ladeur reproach sociological systems theory for the lack of an adequate conceptualization of the network. ${ }^{90}$ In particular, they find fault with Luhmann's separation of the physical sphere of media from the sphere of meaning. ${ }^{91}$ It is true that Luhmann distinguishes "distribution media" (writing, printing, electronic broadcasting, computer networks) from "success media" (symbolically generalized communication media such as property/money, power/law, truth, love, etc.); the former is perceived as crucial means for the distribution of meaning. ${ }^{92}$ Rather than denouncing this as a disadvantage, I would regard it positively as a starting point for conceptualizing the materiality of digital technologies within sociological systems theory. ${ }^{93}$ Whereas Luhmann does not aspire to fully theorize the place of technology in his theory of communication, he clearly shows that the relationship between the communicative dynamics and the material components of the Internet should be conceived as "structural coupling" between machine and social system, ${ }^{94}$ a relationship of "dependent independence." 95 Hence, Luhmann not only separates distribution media and symbolically generalized communication media but also understands the relevance of their mutual interdependencies. ${ }^{96}$ In my view, the distinction between matter and meaning paves the way for a deeper understanding of the complex interrelationship between technology and society in Internet-mediated communicative processes. Moreover, it is the theoretical precondition to enable a critical view of novel technologies and their societal cost.

Another downside of Vesting's and Ladeur's media theory approach is that it is mostly a historical reconstruction of societal and legal evolution. Their ambitious goal is to design a general theory of the history of the law's mediality. The theory reveals a tendency to reconstruct legal communications as cultural artifacts, which carries the risk of becoming overly deferential to technological change.

Finally, while Ladeur is right to highlight the crucial importance of individuals' learning in the digital ecosphere, he underestimates the role of normative behavioral expectations, that is, expectations that are not given up even if violated by interaction partners. As the function of the law is the stabilization and generalization of normative expectations, ${ }^{97}$ Ladeur's narrow focus on cognitive expectations and adaptive behavior neglects normative structures and the law in the digital society. Further, it fails to ask how the law is capable of learning under conditions of computer networks and how it can stimulate reactions to the sociopolitical changes caused by the new technologies.

\section{Conceptualizing the Law's Learning in the Digital Society}

\subsection{Methodological Introduction: Combining STS and Legal Sociology}

With the aim of setting the scene, the previous section reviewed two leading perspectives on the relationship between technology, society, and law. STS provides sophisticated analyses of the complex interactions between society and materiality. The concept of co-production appears to be useful for understanding the mutual interdependencies between designers of technology and the social response. However, regarding its relationship to the law, STS shows its limitations, as a lack of legal expertise prevents this scholarship from understanding the mechanisms of legal doctrine and practice. The media theory approach has designed a general theory about the effect of historically dominant dissemination media on the law. The two main downsides of this perspective are a conceptualization of the computer network as a sociotechnical hybrid (implying an uncritical

\footnotetext{
${ }^{88}$ Ladeur, "Die Netzwerke des Rechts," 160 (translation by the author, CBG).

${ }^{89}$ Ladeur, "Die Netzwerke des Rechts," 157-158; see also Viellechner, "Network of Networks," 521.

90 Vesting, Legal Theory and Media of Law, 447-448.

91 Ladeur, "Warum nach den Medien des Rechts fragen?" 110.

92 Luhmann, Social Systems, 160-161.

93 I have developed this in detail in earlier work. See Graber, "Freedom and Affordances," 221-256.

94 Luhmann, "Autopoiesis," 174.

95 Wielsch, Zugangsregeln, 236-238; see also Graber, "Freedom and Affordances," 235-236.

${ }^{96}$ Luhmann, Theory of Society, 193-194.

${ }^{97}$ Luhmann, Law as a Social System, 147-150.
} 
view of technology) and an underestimation of normative social structures in the digital environment, with the effect that the law's learning is upstaged by a one-sided focus on the learning of "relational subjects."

In the following, a combination of STS and legal sociology will be proposed as a strategy to overcome the identified shortcomings. In contrast to existing law and society literature drawing on STS, ${ }^{8}$ the legal sociology approach adopted by this paper reflects Weber's and Hart's distinction between external and internal aspects of the law. As more fully elaborated elsewhere, ${ }^{99}$ I understand legal sociology as a sub-discipline of the law that mediates between a sociological and legal perspective. While the former is concerned with describing and explaining what "is," the latter's task is to deal with what "ought" to be. This categorization is not meant to pit disciplines against each other but to emphasize that a distinction of observational standpoints allows enlarging scientific complexity. The transfer of knowledge from the social sciences to the legal system requires a distinction of two steps. The first step involves an empiric observation and description of real legal problems and an analysis of their cause from the perspective of social science and social theory. The second step attempts to re-import the gained insights back into the legal system with the aim of furthering the law's improvement. Importantly, the second step presupposes a change of perspective from describing social facts (external perspective) to prescribing normative ends (internal perspective).

\subsection{On the Co-production of Technical Affordances}

To develop a legal sociology theory of how the law learns in the digital society, the concept of "technical affordances" 100 is placed center stage. First, the concept is introduced, and its specific contours are defined. Building on the above STS thesis of co-production, it will then be explained how affordances come into a technology. This will pave the way for elaboration on how technical affordances can theoretically be integrated into a legal sociology approach to better understand how the law learns in the digital society.

The concept of "affordances" was originally coined by the perceptual psychologist James Gibson in $1979 .{ }^{101}$ Gibson argued that animals are capable of perceiving information in their environment selectively. What information is selected depends on its relative importance for the animal's survival. Affordances are, thus, information concerning the environment's possibilities or invitations. Ten years later, the designer Donald Norman adopted and popularized the concept. According to Norman, the concept refers to those aspects of an object's design that define the possibilities of its use. ${ }^{102}$ Norman was mostly concerned with the question of how a certain technological design is perceived by users. Within Gibson's framework, the natural environment is in the foreground, and the relative independence of the environment from the way it is perceived by living systems is emphasized. ${ }^{103}$

Gibson conceives affordances of things as being independent from an observer's perceptual experience of them. ${ }^{104}$ His approach corresponds to Searle's "external realism," that is, the assumption that the natural environment "exists independently of our representations of it." 105 Social reality is different, as we construct it by mutually agreeing on its validity. Thereby we need to distinguish between those features of the world that are "intrinsic to nature" and those "that exist relative to the intentionality of observers, users, etc." 106 Searle's external realism is not only consistent with his conceptual relativism but is the precondition for the latter. "The ontological subjectivity of the socially constructed reality requires an ontologically objective reality out of which it is constructed." 107

Hereafter, the concept of technical affordances is used to describe the opportunities or constraints of a technology ${ }^{108}$ that are co-produced within the processes of material design and social interpretation. Thus, the idea of co-production, prominent in Latour-inspired STS scholarship, is combined with affordance theory. But how do affordances come into a technology? Here Pfaffenberger's metaphor of the "technological drama" 109 is helpful as it distinguishes multi-layered interactions between the

\footnotetext{
${ }^{98}$ For a comprehensive literature review see Cole, "Science, Technology, Society, Law,"; see also Faulkner, "Material Worlds."

${ }^{99}$ Graber, "Legal Sociology,"109-134.

100 Hutchby, "Technologies, Texts, Affordances," 441-456; Hutchby, "Affordances and Analysis," 581-589; Hopkins, "Concept of Affordances," 1-8.

101 Gibson, Ecological Approach; see Natsoulas, “To See Things,” 323-347; Hutchby, “Technologies, Texts, Affordances,” 447

102 Norman, Psychology of Everyday Things, 8

${ }^{103}$ Natsoulas, "To See Things."

${ }^{104}$ Natsoulas, "To See Things," 340.

105 Searle, Construction of Social Reality, 150.

${ }^{106}$ Searle, Construction of Social Reality, 9 (emphasis in the original)

${ }^{107}$ Searle, Construction of Social Reality, 191.

${ }^{108}$ For my critique of scholarship that has extended the concept "affordance" beyond material technologies to include "affordances of the law" see Graber, “Artificial Intelligence," 197.

109 Pfaffenberger, "Technological Dramas," 282-312.
} 
material and the social. ${ }^{110}$ Pfaffenberger's drama consists of three acts. Act 1, "regularization," is about independent or corporate technology designers, the "design constituency," 111 shaping the material design of a technological artifact and advocating their view, in social discourse, of how this technology should be interpreted. The famous example of the knife and whether it is a good or bad tool may serve to illustrate Pfaffenberger's thought. The design constituency may assert its interpretation of a newly designed knife as a good tool that cuts well in the hands of a cook and will defend it against an alternative interpretation that it is a bad tool because one can kill with it. ${ }^{112}$ While the discursive aspects of this act are important, the non-discursive (material) ones must not be forgotten. As Nissenbaum stresses, it is the material characteristics of a technology that allow values to be embedded when an artifact is designed. ${ }^{113}$ Hence, the material characteristics of an artifact do matter to its politics. ${ }^{114}$ In Act 2, "adjustment," those segments of society affected by the newly introduced technological artifact, the "impact constituency," 115 enter the scene. Although the design constituency strives to wrap the artifact in a mythos (e.g., "the knife is good") and define alternative interpretations away, ambiguities will always remain. These, in turn, can be exploited by the impact constituency to create a "counter-mythos" of the technology's ontology and purpose. Act 3, "reconstitution," involves a material (i.e., non-discursive) redesign of the technology by the impact constituency. An example would be the invention of ad-blocking technology as a response to the use of behavior-tracking cookies for advertisement purposes. ${ }^{116}$

The three acts are ideal types of possible action patterns and do not necessarily represent a sequence of events; the second or third act of a concrete drama could very well transform itself into the first act of a new technological drama. The metaphor of the technological drama illustrates how affordances find their way into a technology as a mutual interaction between different constituencies, involving both discursive (social) and non-discursive (material) elements.

\title{
3.3 Bottom-up Emergence of Technology-Related Normative Expectations
}

The theory of technical affordances allows us to reject determinist ideologies wanting to make us believe that networked digital technologies, notably applications of AI, are impenetrable and their effects unavoidable. ${ }^{117}$ Conceiving the design and uptake of a novel technology as a process of co-production does not blur the distinction between sociality and materiality. On the contrary, complex interactions between the social and the material are distinguished at various stages of the process. The dichotomous conception of meaning and matter is a necessary precondition for adopting a social critique of novel technologies. It is required to understand how expectations about the behavior of a specific technological artifact can develop bottom-up from local contexts. If these expectations are cognitive, they adapt as users learn more about the behavior of a specific technology. The question is how it can be theoretically explained that normative expectations can evolve, in addition to cognitive ones. In other words: How is the law able to learn and adapt normative expectations about the behavior of digital technologies?

To answer this question, Weber's theory of bottom-up emergence of new norms from the middle of society needs to be remembered. Although more than a hundred years old, Weber's theory is still a benchmark for more recent sociolegal scholarship as far as intellectual originality, and conceptual clarity is concerned.

Questioning the origin of law, Weber rejects the thesis that law emerges primarily from state-centered legislation enacted according to constitutionally prescribed procedure. Weber writes:

\begin{abstract}
At the present time, they [legal rules] usually arise by way of legislation, i.e., conscious human lawmaking in conformity with the formal constitutional requirements, be they customary or "made," of a given political society. Obviously, this kind of lawmaking is not aboriginal; it is not the normal one even in economically or socially complex and advanced societies. ${ }^{118}$
\end{abstract}

Weber's theory about the birth of new law was most likely written between 1911 and $1914 .{ }^{119}$ It is markedly at variance with the dominant view at that time, in particular Austin's state-centered concept of law, according to which law emerges from the state and is enforced through the threat of state sanctions. ${ }^{120}$ For Weber, the state-centered origin of law is the exception rather than the rule, even under conditions of modernity.

\footnotetext{
${ }^{110}$ For a similar approach to explaining the co-production of affordances see Feenberg, Technosystem, $153-157$.

111 Pfaffenberger, "Technological Dramas," 283.

112 See also Waelbers, Doing Good with Technologies, 18.

113 Nissenbaum, "Preemption to Circumvention," 1367.

114 Nissenbaum, "Preemption to Circumvention," 1378.

115 Pfaffenberger, "Technological Dramas," 296.

116 Graber, "Artificial Intelligence," 199-201

117 Graber, "Artificial Intelligence."

118 Weber, Economy and Society, 753 (emphasis added).

119 Hermes, "Editorischer Bericht," 268-270.

120 Austin, Province of Jurisprudence, 13-20.
} 
According to Weber, legal norms often originate "aboriginally" from mere habituation to practices and evolve in stages from conventional rules to law:

The psychological "adjustment" arising from habituation to an action causes conduct that in the beginning constituted plain habit later to be experienced as binding; then, with the awareness of the diffusion of such conduct among a plurality of individuals, it comes to be incorporated as "consensus" into people's semi- or wholly conscious "expectations" as to the meaningfully corresponding conduct of others. Finally these "consensual understandings" acquire the guaranty of coercive enforcement by which they are distinguished from mere "conventions." 121

These steps describe the process of aboriginal law production as a gradual development from social facts to norms. It starts with individual action, which is social "insofar as its subjective meaning takes account of the behavior of others and is thereby oriented in its course." 122 An individual's psychological attitudes toward the behavior of others may gradually evolve from mere habituation to awareness and then become confirmed expectations about others' behavior. Such contrafactual expectations are called "normative." 123 According to Weber, an order of normative expectations is a "convention" if the reaction to the violation of its rules will result in disapproval within a given social group. ${ }^{124}$ Unlike conventional rules, legal rules are "guaranteed law." 125 For Weber, an order can be called law "if it is externally guaranteed by the probability that physical or psychological coercion will be applied by a staff of people in order to bring about compliance or avenge violation." 126

Weber is convinced that "even in economically or socially complex and advanced societies," 127 the state is not the only source of law, and normative patterns continue to emerge from social life. As with the net neutrality debate in the United States and European Union, this continues to be true under digital conditions. ${ }^{128}$ Weber's theory of aboriginal law production is, thus, a fruitful starting point for a reflection on the law's learning capabilities in the digital society. In my view, a theory about the growth of normative expectations need not be limited to the behavior of human actors but can extend to expectations about the behavior of other "actants," including digital agents and their affordances. In the following, the Facebook "Like" button will serve as an example of empirical evidence in support of my thesis.

In 2007, Leah Pearlman, a designer at Facebook, observed that people only rarely commented on their friends' updates, and she thought that everybody would benefit from more interaction. Pearlman suspected that "if people did not have anything new or clever to say they would not say anything at all," ${ }^{129}$ and if people had nothing witty to respond to a friend's post but still had a positive feeling about it, they would rather leave a single word such as "awesome." 130 However, dozens or hundreds of "awesome" responses would fill up the Facebook page and not look nice. To avoid that, she and Justin Rosenstein, a colleague at Facebook, designed an "Awesome" button, which would display next to every post. ${ }^{131}$ A click would be all that people needed to express support for one another. The designers' aim was to wake up the positivity drowsing in every Facebook user. They envisioned that pressing a button would provide a path of least resistance for people otherwise hesitating to engage in more interaction. ${ }^{132}$ The idea went down well with Facebook's management, and after a name change from "Awesome" to "Like," a little blue-and-white thumbs-up icon was officially activated on February 9, 2009. ${ }^{133}$

Very soon, it became evident that Pearlman and Rosenstein's public-interest-oriented interpretation of the "Like" button was not the only possible one. In a discursive process within the Facebook design constituency, the analytics department and the business managers competed for the "valid" interpretation of the newly designed artifact's affordances. ${ }^{134}$ The analytics department perceived the Like button as a means for harvesting detailed information about user behavior, which would be useful for tailoring content more precisely to a user's personal profile. The business managers also adopted this interpretation of the artifact's affordances because the personalization of content offered the potential for selling individualized ads to the advertising industry.

\footnotetext{
${ }^{121}$ Weber, Economy and Society, 754.

${ }^{122}$ Weber, Economy and Society, 4.

${ }^{123}$ Luhmann, Law as a Social System, 147-150.

${ }^{124}$ Weber, Economy and Society, 34.

${ }^{125}$ Weber, Economy and Society, 313.

${ }^{126}$ Weber, Economy and Society, 34 (emphasis in the original).

127 Weber, Economy and Society, 753.

${ }^{128}$ Graber, "Bottom-up Constitutionalism," 524-552.

129 Pearlman, "Do You Like Me?"

130 Thompson, Coders, 143.

${ }^{131}$ Rosenstein, "No Dislike Button."

${ }^{132}$ Luckerson, "Rise of Like Economy."

${ }^{133}$ Kincaid, "Facebook Activates 'Like'."

${ }^{134}$ See Thompson, Coders, 144
} 
We now know that the business-oriented interpretation of the plugin eventually won and that, in the meantime, the Like button "made Facebook billions." 135 As the plugin rapidly became a huge success, Facebook published "copy and paste" software so that any website could furnish any post with a Like button. Every time a user visited a website with a Like button on it, his or her personal data were transferred to Facebook, even if the visitor was not a member of Facebook or had never clicked on the button. ${ }^{136}$

Pearlman and Rosenstein were unable to resign themselves to the fact that instead of their public-interest-oriented interpretation of the Like button, an interpretation had prevailed in the design constituency that permitted Facebook to maximize advertising revenues. They left the social network and became vocal critics in the Facebook impact constituency of what they denounced as a further step toward an economization of the Internet. ${ }^{137}$ The two turned into important protagonists of a discourse that was oriented to creating a "counter-mythos" for the Like button, invigorating alternative interpretations of its affordances. They warned the Internet community against the negative side effects of their invention and raised awareness of the dangers relating to massively collecting personal user data and the addictive potential of the Like button. Many Internet activists followed their critique with the aim of preventing a "normalization" of a specific interpretation of the Like button and maintaining the possibility of a sociopolitical correction. According to Pfaffenberger, "normalization" or "designification" refers to a situation where certain social and technological dynamics lead to ending the dialogue between the design constituency and the impact constituency, letting a specific "mythos" about the artifact appear as unalterable. ${ }^{138}$

This process can be reconstructed as the emergence of normative expectations about the affordances of a new technology from the bottom of society. The mythos of the Like that was favored by Facebook management was rejected by protagonists in the impact constituency and combated with a counter-mythos condemning the plugin as a mechanism promoting "psychologically manipulative advertising." 139 The resistance, orchestrated by Internet activists, consumer organizations, and scientists was justified with reference to values and norms that are expected to be valid in the digital society.

\subsection{Generalization of Normative Expectations and Institutionalization as Law}

What determines whether normative expectations about novel technologies are stabilized and generalized as legal norms? The discussion of the "Fashion ID" case below will explain for the law of the EU that legislation and judicial adjudication can both play a key role in this. As behavioral expectations about new technologies evolve gradually in civil society and politics, there is usually a gap between the deployment of a new technology and a regulatory reaction. ${ }^{140}$ Often, it is the courts leading the way, as the "Google thumbnails" and "Right to be Forgotten" cases demonstrate. In the latter case, in a conflict between Google and the Spanish Data Protection Agency, the CJEU recognized the "Right to be Forgotten" as a new fundamental right of EU law. ${ }^{141}$ The court held that a user has a right to request that certain information on the Internet no longer be linked to his name by a list of results displayed following a search made on his name. For the implementation of this decision, Google faced the problem of how to operationalize the new fundamental right within its search algorithms. Google's problem was partly resolved when the EU eventually included detailed provisions about the "Right to be Forgotten" into its General Data Protection Regulation (GDPR), ${ }^{142}$ which entered into force on May 25, 2018. The case confirms Zittrain's observation that normative expectations are mostly "unsettled" at an early stage of a technology's uptake, and the judges who are called upon to apply the law in such contexts often have not "fully experienced the technologies in question." 143

The net neutrality debate in Europe is an example of a settled sociopolitical response to a novel technology, which eventually resulted in directly applicable and binding EU legislation on access to the open Internet and net neutrality. ${ }^{144}$ Article 3(3) of the Open Internet Regulation states that providers of Internet access services may apply only those traffic management measures, which are transparent, non-discriminatory, and proportionate, and are not based on commercial considerations. The CJEU has

\footnotetext{
135 Kessler, "Made Facebook Billions."

${ }^{136}$ Fashion ID v Verbraucherzentrale NRW, CJEU, Case C-40/17, July 29, 2019, para 27.

${ }^{137}$ Lewis, "Minds can be Hijacked."

138 Pfaffenberger, "Technological Dramas," 308. Feenberg, Technosystem, 101, uses the term "closure" in this context.

${ }^{139}$ Lewis, "Minds can be Hijacked."

${ }^{140}$ Similarly, Zittrain, Future of the Internet, 122.

141 "Right to be Forgotten," CJEU, C-131/12, May 13, 2014.

${ }^{142}$ Regulation EU 2016/679 of the European Parliament and of the Council of April 27, 2016 on the protection of natural persons with regard to the processing of personal data and on the free movement of such data, OJ $2016 \mathrm{~L} 119 / 1$

${ }^{143}$ Zittrain, Future of the Internet, 122.

${ }^{144}$ Regulation (EU) 2015/2120 of the European Parliament and of the Council of November 25, 2015 setting out measures concerning open Internet access (Open Internet Regulation), OJ 2015 L 310/1. This is a directly applicable legal instrument introducing binding rules on net neutrality, which regulate the relationship between Telecom companies and their customers in a general and abstract manner. See Graber, "Bottom-up Constitutionalism," 549-552.
} 
interpreted this provision in the recent Telenor $v$ Hungary decision and decided that a so-called "zero-rating" 145 agreement does not fulfill these requirements because it is based on commercial considerations. ${ }^{146}$ As evidenced by this decision, it is generally up to the courts to clarify the interpretation of statutory provisions regulating a new technology and to advance legal certainty by handing down leading judgments on contentious legal questions in complex application contexts.

Another example of a court applying statutory norms is the "Fashion ID" decision of the CJEU of July 29, 2019. In that case, the court clarified that the EU already provides data protection regulation covering the effects of the Facebook Like button on Internet users' personal data. The ruling involved "Fashion ID," a fashion retailer, which had embedded the Facebook Like button on its website. ${ }^{147}$ The CJEU found that whenever a user visited the Fashion ID website, the social plugin transmitted protected personal data, including the user's IP address, information on the desired content, and the browser's technical data, to Facebook (Ireland). ${ }^{148}$ The court determined that this happened "regardless of whether or not the visitor is a member of the social network Facebook, has clicked on the Facebook "Like" button or is aware of such an operation." 149 The court further ruled that both Fashion ID and Facebook are "data controllers"; consequently, both must comply with EU data protection law. According to the CJEU, such data processing is only legal if the data subject (the user) gives consent prior to the data collection. Consent given to Facebook alone would not be enough. The court specified that "to guarantee efficient and timely protection, it is for the webpage operator, rather than for the plugin provider, to obtain consent." ${ }^{150}$ This ruling, thus, exemplifies how normative expectations that have emerged from civil society interactions have been reformulated by a major court in the language of the law, resulting in a binding and enforceable decision.

\section{Conclusion}

The Facebook Like button example illustrates the co-production of a novel technology's affordances. Expanding Weber's theory of aboriginal law production to cyberspace, the process can be reconstructed to start in a civil society context involving the eventual emergence of normative expectations about an artifact's affordances. The process then shifts to the legal system, where the newly emerged normative expectations are stabilized, generalized, and institutionalized as legal norms. The Fashion ID decision of the CJEU is an example of a court applying existing general and abstract norms (the EU data protection legislation) to a novel technology (the Facebook plugin) and, thus, leading to condensation and confirmation ${ }^{151}$ of normative expectations in more specified factual contexts. In declaring that both Fashion ID and Facebook are data controllers, both corporations are held accountable to comply with EU data protection legislation. Consequently, no data can be collected or transmitted by a Facebook plugin that is placed on a third-party website without a consumer's prior consent. The determinations made by the court reveal how normative expectations of Internet users and tech companies are rebalanced and how legal doctrine is adapted to effectively protect the privacy rights of Internet users in a changing digital environment.

The evolution of normative expectations about novel technological artifacts often depends on whether the artifact's affordances are visible or not. In the context of AI or other applications of "pre-emptive computing," 152 technical affordances are often concealed. To facilitate a sociopolitical response, I would recommend the development of procedures aimed at blocking known affordances that cause social costs. Conversely, procedures should be designed to bring affordances to the surface that, from a public interest perspective, are positively valued but risk remaining hidden if critical actors or new societal perspectives are not able to work toward their detection. ${ }^{153}$ To enhance the discovery process, discourses should be politically institutionalized and be as inclusive as possible, encompassing not only experts, politicians, and schools at all levels of education but also broad segments of civil society (activists, hackers, NGOs, consumer organizations, etc.). Government regulation could contribute to the institutionalization of discourse conditions that facilitate the detection of positively valued affordances and the legal institutionalization of normative expectations.

\footnotetext{
${ }^{145}$ Simply put, zero rating is a commercial practice whereby an Internet access provider exempts certain data traffic from any caps in place for Internet access or extra charges if a cap is exceeded. Graber, "Bottom-up Constitutionalism," 549.

146 Telenor v Hungary, CJEU, Cases C-807/18 and C-39/19, September 15, 2020, para 54.

${ }^{147}$ Fashion ID v Verbraucherzentrale NRW, CJEU, C-40/17, July 29, 2019.

${ }^{148}$ Fashion ID v Verbraucherzentrale NRW, CJEU, C-40/17, July 29, 2019, para 85.

${ }^{149}$ Fashion ID v Verbraucherzentrale NRW, CJEU, C-40/17, July 29, 2019, para 75.

${ }^{150}$ Fashion ID v Verbraucherzentrale NRW, CJEU, C-40/17, July 29, 2019, para 102.

151 The double concept of condensation and confirmation is used by Luhmann, Theory of Society, 38, to describe the re-actualization of identical meaning in new situations.

${ }^{152}$ Hildebrandt, Smart Technologies, 170.

${ }^{153}$ Feenberg, Technosystem, 32.
} 


\section{Bibliography}

Austin, John. The Province of Jurisprudence Determined (1832). Reprinted in London: Weidenfeld \& Nicolson, 1954.

Biagioli, Mario and Marius Buning. "Technologies of the Law/Law as a Technology.” History of Science 57, no 1 (2019): $3-$ 17. https://doi.org/10.1177\%2F0073275318816163

Bijker, Wiebe E. "Technology, Social Construction of." In International Encyclopedia of the Social \& Behavioral Sciences, 2nd edn, edited by James D. Wright, 135-140. Oxford: Elsevier, 2015.

Cockfield, Arthur and Jason Pridmore. "A Synthetic Theory of Law and Technology." Minnesota Journal of Law, Science \& Technology 8, no 2 (2007): 475-513.

Cole, David. "The Chinese Room Argument." In The Stanford Encyclopedia of Philosophy, spring edition, edited by Edward N. Zalta, para 5.2, 2020. https://plato.stanford.edu/archives/spr2020/entries/chinese-room/

Cole, Simon A. and Alyse Bertenthal. "Science, Technology, Society, and Law." Annual Review of Law and Social Science 13, no 1 (2017): 351-371. https://doi.org/10.1146/annurev-lawsocsci-110316-113550

Couldry, Nick. "Recovering Critique in an Age of Datafication." New Media \& Society 22, no 7 (2020): 1135-1151. https://doi.org/10.1177\%2F1461444820912536

Doherty, Neil F., Crispin R. Coombs, and John Loan-Clarke. "A Re-conceptualization of the Interpretive Flexibility of Information Technologies: Redressing the Balance Between the Social and the Technical." European Journal of Information Systems 15, no 6 (2006): 569-582. https://doi.org/10.1057/palgrave.ejis.3000653

Faulkner, Alex, Bettina Lange, and Christopher Lawless. "Introduction: Material Worlds: Intersections of Law, Science, Technology, and Society.” Journal of Law and Society 39, no 1 (2012): 1-19. https://doi.org/10.1111/j.14676478.2012.00567.x

Feenberg, Andrew. Technosystem: The Social Life of Reason. Cambridge, MA: Harvard University Press, 2017.

Feenberg, Andrew. "A Critical Theory of Technology.” In The Handbook of Science and Technology Studies, edited by Ulrike Felt, Rayvon Fouché, Clark A. Miller and Laurel Smith-Doerr, 635-663. Cambridge, MA; London, England: The MIT Press, 2017.

Geyer, Stefan. Die Unterwerfung der Zeichen. Zürich: Chronos, 2020.

Gibson, James J. The Ecological Approach to Visual Perception. Boston, MA: Houghton Mifflin, 1979.

Giere, Ronald. "What Everyone Should Know about STS.” Social Studies of Science 36, no 3 (2006): 489-493.

Graber, Christoph B. "Bottom-up Constitutionalism: The Case of Net Neutrality." Transnational Legal Theory 7, no 4 (2017): 524-552. https://doi.org/10.1080/20414005.2017.1300678

Graber, Christoph B. "Freedom and Affordances of the Net." Washington University Jurisprudence Review 10 (2018): 221256.

Graber, Christoph B. "Legal Sociology.” In Introduction to Swiss Law, edited by Marc Thommen, 109-134. Berlin: Carl Grossmann Verlag, 2018.

Graber, Christoph B. "Artificial Intelligence, Affordances and Fundamental Rights." In Life and the Law in the Era of DataDriven Agency, edited by Mireille Hildebrandt and Kieron O’Hara, 194-213. Cheltenham, UK: Edward Elgar, 2020.

Grint, Keith and Steve Woolgar. The Machine at Work: Technology, Work and Organization. Cambridge: Polity Press, 1997.

Hart, H. L. A. The Concept of Law. Oxford: Clarendon Press, 1961.

Headland, Thomas N., Kenneth Pike, and Marvin Harris (eds). Emics and Etics: The Insider/Outsider Debate. Newbury Park, CA: Sage Publications, 1990.

Hermes, Siegfried. "Editorischer Bericht zu 'Die Entwicklungsbedingungen des Rechts'.” In Max Weber. Wirtschaft und Gesellschaft. Die Wirtschaft und die gesellschaftlichen Ordnungen und Mächte. Nachlass. Teilband 3, Recht, Max Weber Gesamtausgabe, I, 22/3, edited by Werner Gephart and Siegfried Hermes, 249-272. Tübingen: Mohr Siebeck, 2010.

Hildebrandt, Mireille. Smart Technologies and the End(s) of Law: Novel Entanglements of Law and Technology. Cheltenham, UK; Northampton, MA: Edward Elgar, 2015.

Hopkins, Julian. "The Concept of Affordances in Digital Media." In Handbuch Soziale Praktiken und Digitale Alltagswelten, edited by Heidrun Friese, Gala Rebane, Marcus Nolden and Miriam Schreiter, 1-8. Wiesbaden: Springer, 2016.

Hutchby, Ian. "Technologies, Texts and Affordances." Sociology 35, no 2 (2001): 441-456. https://doi.org/10.1177\%2FS0038038501000219

Hutchby, Ian. "Affordances and the Analysis of Technologically Mediated Interaction: A Response to Brian Rappert." Sociology 37, no 3 (2003): 581-589. https://doi.org/10.1177\%2F00380385030373011

Ihde, Don. Technology and the Lifeworld: From Garden to Earth. Bloomington and Indianapolis: Indiana University Press, 1990.

Jasanoff, Sheila. Science at the Bar: Law, Science, and Technology in America. Cambridge, MA: Harvard University Press, 1995.

Jasanoff, Sheila. "Science and Judgment in Environmental Standard Setting." Applied Measurement in Education 11, no 1 (1998): 107-120. https://doi.org/10.1207/s15324818ame1101_7 
Jasanoff, Sheila. "Between Risk and Precaution-Reassessing the Future of GM Crops." Journal of Risk Research 3 , no 3 (2000): 277-282. https://doi.org/10.1080/13669870050043161

Jasanoff, Sheila. "Law’s Knowledge: Science for Justice in Legal Settings.” American Journal of Public Health 95 (2005): S49-S58. https://doi.org/10.2105/AJPH.2004.045732

Jasanoff, Sheila. "Just Evidence: The Limits of Science in the Legal Process.” Journal of Law, Medicine \& Ethics 34 (2006): 328-341. https://doi.org/10.1111\%2Fj.1748-720X.2006.00038.X

Jasanoff, Sheila. "Making Order: Law and Science in Action.” In The Handbook of Science and Technology Studies, 3rd edn, edited by Edward J. Hackett, Olga Amsterdamska, Michael Lynch and Judy Wajcman, 761-786. Cambridge, MA: The MIT Press, 2008.

Jasanoff, Sheila. “The Idiom of Co-Production." In States of Knowledge: The Co-Production of Science and Social Order, edited by Sheila Jasanoff, 1-12. London: Routledge, 2010.

Karavas, Vagias. "The Force of Code: Law’s Transformation under Information Technological Conditions." German Law Journal 10, no 4 (2009): 463-481. https://doi.org/10.1017/S2071832200001164

Kessler, Andy. "The Button That Made Facebook Billions.” The Wall Street Journal, February 2, 2012. https://www.wsj.com/articles/SB10001424052970204652904577196992203069570

Kincaid, Jason. “Facebook Activates 'Like’ Button.” TechCrunch, February 9, 2009. https://techcrunch.com/2009/02/09/facebook-activates-like-button-friendfeed-tires-of-sincere-flattery/

Kline, Ronald R. “Technological Determinism.” In International Encyclopedia of the Social \& Behavioral Sciences, 2nd edn, edited by James D. Wright, 109-112. Oxford: Elsevier, 2015.

Korsgaard, Christine M. Fellow Creatures: Our Obligations to the Other Animals. Oxford: Oxford University Press, 2018.

Krämer, Sybille. Medium, Messenger, Transmission: An Approach to Media Philosophy. Amsterdam: Amsterdam University Press, 2015.

Ladeur, Karl-Heinz. “Toward a Network-Oriented Law of the Internet!” German Law Journal 10, no 9 (2009): 1201-1214. https://doi.org/10.1017/S2071832200018101

Ladeur, Karl-Heinz. "Die Netzwerke des Rechts und die Evolution der 'Gesellschaft der Netzwerke'.” In Netzwerke in der funktional differenzierten Gesellschaft, edited by Michael Bommes and Veronika Tacke, 143-171.Wiesbaden: VS Verlag, 2011.

Ladeur, Karl-Heinz. "Warum nach den Medien des Rechts fragen?” Ancilla Iuris (2012): 105-110.

Ladeur, Karl-Heinz. "Die Gesellschaft der Netzwerke und ihre Wissensordnung: Big Data, Datenschutz und die 'relationale Persönlichkeit'.” In Die Gesellschaft der Daten: Über die digitale Transformation der sozialen Ordnung, edited by Florian Süssenguth, 225-252. Bielefeld: transcript, 2015.

Ladeur, Karl-Heinz. "Die Zukunft der Medienverfassung.” In Die Zukunft der Medienverfassung, edited by Karl-Heinz Ladeur, Christoph Beat Graber, Albert Ingold and Dan Wielsch, 17-89. Tübingen: Mohr Siebeck, 2021.

Latour, Bruno. Science in Action: How to Follow Scientists and Engineers through Society. Cambridge, MA: Harvard University Press, 1987.

Latour, Bruno. We Have Never Been Modern. Translated by Catherine Porter. Cambridge, MA: Harvard University Press, 1993 (1991).

Latour, Bruno. Politics of Nature: How to Bring the Sciences into Democracy. Translated by Catherine Porter. Cambridge, MA: Harvard University Press, 2004 (1999).

Latour, Bruno. The Making of Law: An Ethnography of the Conseil d'Etat. Translated by Marina Brilman and Alain Pottage. Cambridge: Polity Press, 2010 (2002).

Law, John. "STS as Method." In The Handbook of Science and Technology Studies, edited by Ulrike Felt, Rayvon Fouché, Clark Miller and Laurel Smith-Doerr, 31-57. Cambridge, MA; London, England: The MIT Press, 2017.

Law, John and Vicky Singleton. "Performing Technology's Stories: On Social Constructivism, Performance, and Performativity." Technology and Culture 41, no 4 (2000): 765-775. https://doi.org/10.1353/tech.2000.0167

Levi, Ron and Maria Valverde. "Studying Law by Association: Bruno Latour Goes to the Conseil d'Etat." Law \& Social Inquiry 33, no 3 (2008): 805-825. https://doi.org/10.1111/j.1747-4469.2008.00122.x

Lewis, Paul. "'Our Minds can be Hijacked': The Tech Insiders Who Fear a Smartphone Dystopia.” The Guardian, October 6, 2017. https://www.theguardian.com/technology/2017/oct/05/smartphone-addiction-silicon-valley-dystopia

Luckerson, Victor. "The Rise of the Like Economy.” The Ringer, February 15, 2017. https://www.theringer.com/2017/2/15/16038024/how-the-like-button-took-over-the-internet-ebe778be2459

Luhmann, Niklas. "The Autopoiesis of Social Systems." In Sociocybernetic Paradoxes: Observation, Control, and Evolution of Self-Steering Systems, edited by R. F. Geyer and Johannes van der Zouwen, 172-192. London; Beverly Hills, CA: Sage Publications, 1986.

Luhmann, Niklas. Social Systems. Translated by John Bednarz. Stanford, CA: Stanford University Press, 1995 (1984).

Luhmann, Niklas. Law as a Social System. Translated by Klaus Alex Ziegert. Oxford; New York: Oxford University Press, 2004 (1993). 
Luhmann, Niklas. Theory of Society, Vol. I. Translated by Rhodes Barret. Stanford, CA: Stanford University Press, 2012 (1997).

Lynch, Michael (ed.) Science and Technology Studies: Critical Concepts in the Social Sciences. London; New York: Routledge Taylor \& Francis Group, 4 volumes, 2012.

Lynch, Michael and Simon Cole. "Science and Technology Studies on Trial." Social Studies of Science 35, no 2 (2005): 269311. https://doi.org/10.1177\%2F0306312705048715

Lynch, Michael, Simon A. Cole, Ruth McNally, and Kathleen Jordan. Truth Machine: The Contentious History of DNA Fingerprinting. Chicago: University of Chicago Press, 2010.

McLuhan, Marshall. Understanding Media: The Extensions of Man. Cambridge, MA: MIT Press, 1994 (1964).

Mostowlansky, Till and Andrea Rota. "Emic and Etic." In The Cambridge Encyclopedia of Anthropology, edited by Joel Robbins, Felix Stein, Sian Lazar, Matei Candea, Hildegard Diemberger, Andrew Sanchez and Rupert Stasch, 1-16. Cambridge: University of Cambridge, 2020.

Natsoulas, Thomas. "'To See Things is to Perceive What They Afford': James J. Gibson's Concept of Affordance.” The Journal of Mind and Behavior 25, no 4 (2004): 323-347.

Nissenbaum, Helen. "From Preemption to Circumvention: If Technology Regulates, Why Do We Need Regulation (and Vice Versa)?” Berkeley Technology Law Journal 26 (2011): 1367-1386. http://dx.doi.org/10.15779/Z38BQ3P

Norman, Donald A. The Psychology of Everyday Things. New York: Basic Books, 1988.

Pearlman, Leah. “Do You Like Me? Do I?” TEDx Talk, October 31, 2016. https://www.youtube.com/watch?v=5nwSjRA3kQA

Pfaffenberger, Bryan. “Technological Dramas.” Science, Technology \& Human Values 17, no 3 (1992): $282-312$. https://doi.org/10.1177\%2F016224399201700302

Pinch, Trevor J. and Wiebe E. Bijker. "The Social Construction of Facts and Artifacts: Or How the Sociology of Science and the Sociology of Technology Might Benefit Each Other." In The Social Construction of Technological Systems: New Directions in the Sociology and History of Technology, edited by Wiebe E. Bijker, Thomas P. Hughes, and Trevor Pinch, 17-50. Cambridge, MA: MIT Press, 1987.

Pottage, Alain. "Biotechnology as Environmental Regulation." In Law and Ecology: New Environmental Foundations, edited by Andreas Philippopoulos-Mihalopoulos, 105-125. Oxford, UK: Routledge, 2011.

Pottage, Alain. “The Materiality of What?” Journal of Law and Society 39, no 1 (2012): 167-183. https://doi.org/10.1111/j.1467-6478.2012.00576.x

Rosenstein, Justin. "No Dislike Button on Facebook.” Stanford University eCorner, May 8, 2013. https://ecorner.stanford.edu/in-brief/no-dislike-button-on-facebook/

Sayes, Edwin. "Actor-Network Theory and Methodology: Just What does it Mean to Say that Nonhumans have Agency?" Social Studies of Science 44, no 1 (2014): 134-149. https://doi.org/10.1177\%2F0306312713511867

Searle, John R. The Construction of Social Reality. London: Penguin, 1995.

Sismondo, Sergio. An Introduction to Science and Technology Studies, 2nd edn. Chichester: Wiley-Blackwell, 2010.

Smith, Barbara Herrnstein. "The Unquiet Judge: Activism Without Objectivism in Law and Politics." In Science and Technology Studies: Critical Concepts in the Social Sciences, 4 volumes, edited by Michael Lynch. London; New York: Routledge Taylor \& Francis Group, 2012.

Teubner, Gunther. "How the Law Thinks: Toward a Constructivist Epistemology of Law." Law \& Society Review 23, no 5 (1989): 727-757. https://psycnet.apa.org/doi/10.2307/3053760

Thier, Andreas. "Recht, Rechtswissenschaft und Medialität." NCCR Mediality Newsletter, 7-15.

Thompson, Clive. Coders: The Making of a New Tribe and the Remaking of the World. New York: Penguin Press, 2019.

Verbeek, Peter-Paul. "Artifacts and Attachment: A Post-Script Philosophy of Mediation.” In Inside the Politics of Technology: Agency and Normativity in the Co-Production of Technology and Society, edited by Hans Harbers, $125-146$. Amsterdam: Amsterdam University Press, 2005.

Vesting, Thomas. "Legal Theory as Media Theory." Ancilla Iuris (2010): 47-88.

Vesting, Thomas. Legal Theory and the Media of Law. Translated by James C. Wagner. Cheltenham, UK; Northampton, MA: Edward Elgar Publishing, 2018.

Viellechner, Lars. “The Network of Networks: Karl-Heinz Ladeur's Theory of Law and Globalization.” German Law Journal 10, no 4 (2009): 515-536. https://doi.org/10.1017/S207183220000119X

Waelbers, Katinka. Doing Good with Technologies: Taking Responsibility for the Social Role of Emerging Technologies. Dordrecht: Springer, 2011.

Weber, Max. Economy and Society: An Outline of Interpretive Sociology. Translated by Günther Roth. Berkeley: University of California Press, 1978 (first published 1922 in German).

Wielsch, Dan. Zugangsregeln: Die Rechtsverfassung der Wissensteilung. Tübingen: Mohr Siebeck, 2008.

Woolgar, Steve and Geoff Cooper. “Do Artefacts Have Ambivalence?” Social Studies of Science 29, no 3 (1999): $433-449$. https://doi.org/10.1177\%2F030631299029003005 
Zammito, John H. A Nice Derangement of Epistemes: Post-Positivism in the Study of Science from Quine to Latour. Chicago: University of Chicago Press, 2004.

Zittrain, Jonathan. The Future of the Internet and How to Stop it. New Haven, CT: Yale University Press, 2008.

\section{Primary Legal Material}

\section{European Union}

Fashion ID v Verbraucherzentrale NRW, CJEU, C-40/17, July 29, 2019.

"Right to be Forgotten," CJEU, C-131/12, May 13, 2014.

Telenor v Hungary, CJEU, Cases C-807/18 and C-39/19, September 15, 2020.

Regulation EU 2016/679 of the European Parliament and of the Council of April 27, 2016, on the protection of natural persons with regard to the processing of personal data and on the free movement of such data, OJ 2016 L $119 / 1$.

Regulation (EU) 2015/2120 of the European Parliament and of the Council of November 25, 2015, setting out measures concerning open Internet access (Open Internet Regulation), OJ 2015 L 310/1.

\section{Germany}

“Thumbnails I," Bundesgerichtshof, I ZR 69/08, April 29, 2010.

“Thumbnails II," Bundesgerichtshof, I ZR 140/10, October 19, 2011.

\section{United States}

United States Telecom Association v FCC, USCA 15-1063 (DC Circuit), June 14, 2016. 